PAPER ID - ICAE 2014, 710

\title{
Foreign versus Indigenous Innovation and Energy Intensity: Further Research across Chinese Regions
}

\author{
$\begin{array}{lll}\text { M.J. Herrerias } & \text { A. Cuadros } & \text { D. Luo }\end{array}$ \\ ${ }^{1}$ University of Birmingham \\ Department of Economics \\ ${ }^{2}$ Universitat Jaume I \\ Department of Economics \& Institute of International Economics \\ ${ }^{3}$ University of Nottingham \\ School of Contemporary Chinese Studies
}

1 September 2014

\begin{abstract}
The aim of this work is to analyze the role played by both foreign and indigenous innovation on energy intensity as well as the possible interactions between them across 30 Chinese regions. In addition, we disaggregate non-state investment into the different types of corporate ownership that operate in China, controlling for other relevant factors such as energy price and the share of industry. We examine not only total energy intensity, but also coal, crude oil, natural gas, and electricity in order to provide a complete picture of the energy sector in this country. The empirical model is estimated by panel-corrected standard errors over the period 2006-2010. Our findings indicate that the process of technological change through both foreign and indigenous innovation has been an important mechanism to improve the use of energy resources. However, the interaction between foreign and indigenous innovations is modest. We also observe that non-state investment plays a key role in reducing energy intensity, although both the specific type of ownership and the source of energy also matter. A closer look at regional differences among the transmission grids in China reveals the importance of accounting for the structure of investment and its geographical location.
\end{abstract}

Key words Energy intensity, Investment ownership, Chinese regions, Technology transfer, Indigenous and foreign innovation.

JEL Classification: O24, Q4, 053, P28

Corresponding author: M.J. Herrerias, University of Birmingham, Department of Economics, Edgbaston, Birmingham, B15 2TT, United Kingdom.

E-mail address: m.j.herrerias@bham.ac.uk

${ }^{2}$ Email: cuadros@uji.es
${ }^{3}$ Email $\underline{\text { d.luo@nottingham.ac.uk }}$

Acknowledgments: Ana Cuadros gratefully acknowledges financial support from the Spanish Ministerio de Ciencia e Innovación (ECO2011-28155/ECON) and Pla de Promoció de la Investigació Fundació Caixa Castelló-Bancaixa (P1.1B2013-22). Authors acknowledge the comments received from Vicente Orts in a previous version of the paper.

Previous versions of this paper were running under the title: Ownership Reform, Innovation and Energy Intensity: Further Research across Chinese Regions. 
1

2

3

4

5

6

7

\section{Introduction}

The fast process of industrialization has led the Chinese economy to consume a significant amount of energy resources, thereby becoming one of the most important consumers in the world today. However, the exceptional performance of this economy and the rate at which energy is consumed are not free of cost. China is currently facing a new scenario, where environmental pollution as well as problems in the supply of energy are the core of a debate taking place in this country due to their expected consequences on economic growth and the welfare of the population. Nonetheless, such concerns are a relatively recent phenomenon. Indeed, the $11^{\text {th }}$ Five-Year Plan (20062010) was the first attempt to promote further reforms in the energy sector. This has been complemented by the $12^{\text {th }}$ Five-Year Plan (FYP) (2011-2015), which set up several key targets to be reached by 2015 , such as reducing pollutant emissions and energy consumption per unit of GDP by $17 \%$ and $16 \%$ respectively. Such a change in energy policies contrasts sharply with the previous period (before 2006) during which China paid little attention to achieving any environmental goals. This can be explained by the fact that energy-saving measures were seen by the Chinese government as a constraint on economic growth. However, relatively recent evidence shows that the Chinese economy can adopt energy-saving measures without interrupting the path toward economic growth (Herrerias et al., [1]). Thus, the key question to be answered is: What types of policies can be adopted by the government to improve energy efficiency and prevent global warming? This paper offers some new insights on this issue.

In the energy economics literature, one of the strongest debates has been focused on energy intensity. This is a simple measure of the degree of efficiency in the use of energy resources, and it is used as a key indicator to design energy policies among the 
27 developed and developing countries. Changes in energy efficiency can be attributed to

28 technological progress and sectorial composition (Zhang, [2]; Fisher-Vanden et al., [3];

29 Fisher-Vanden et al., [4]; Liao et al., [5]; Ma and Stern, [6]; Herrerias et al., [12]). On

30 the one hand, there is an agreement in the literature on the role played by the

31 technological progress, however few works have disentangled the specific mechanisms

32 through which it may operate. On the other hand, the effect of the composition effect

33 would depend on the stage of economic development of different countries or regions

34 e.g. moving away from heavy industry sectors towards light industry or vice versa and

35 the shift from agriculture to industry. In this work, we focus on the technique effect,

36 where we distinguish foreign and indigenous innovations as key factors to improve

37 energy efficiency across Chinese regions. This distinction is important because

38 economic policies adopted by the government can affect the economy directly or

39 indirectly, modifying the incentives in the use of energy and stimulating the

40 technological innovation. In the case of the Chinese economy, the open-door policy has

41 increased the efficiency in the allocation of economic resources and enhanced the role

42 played by trade and foreign direct investment as mechanisms for knowledge transfer. In

43 addition, higher efforts towards the alleviation of pollution and improvement of energy

44 efficiency have been made since 2006 for its relevance on the sustainability of

45 economic growth. These policies influence the incentives to innovate through both

46 indigenous and foreign technology.

47 Despite the relevance of foreign and indigenous innovations as sources of 48 technological progress, their potential contribution to the advancement in energy 49 efficiency, as well as the interactions that may exist between them, they have been

50 ignored in the relevant literatures. In this paper, foreign technology is measured by 51 foreign direct investment (FDI) and imports, while indigenous innovations are captured 
52 by patents. On one hand, FDI has been found to be a suitable mechanism for technology

53 transfer, which might affect productivity through spillover effects and also incorporates

54 new technologies into the production process through the accumulation of physical

55 capital. In addition, the presence of multinationals in the host economy may stimulate

56 competition with local firms, encouraging them to use existing technologies more

57 efficiently (Sjöholm and Lundin, [8]). In the international trade literatures, imports have

58 been considered as an important channel for the international diffusion of knowledge

59 due to the embodied technological progress in capital goods imports (Herrerias and

60 Orts, [7]). On the other hand, indigenous innovation can emerge from the

61 aforementioned competition effect and also from the implementation of innovation

62 policies. They may stimulate the emergence of new discoveries or knowledge, thus

63 improving efficiency and productivity. However, indigenous innovations could also be

64 influenced by a country's characteristics, such as the structure of ownership investment,

65 as it may condition the effectiveness of incentives.

66 In the case of China, the transformation of the state sector and the emergence of new

67 forms of investment ownership have been one of the fundamental keys to understand

68 the process of China's transition from a planned to a market economy. The share-

69 holding program initiated in the mid-1990s became the principal vehicle for

70 implementing the ownership reform of the State-owned enterprises (SOEs) by the

71 government (Jefferson and $\mathrm{Su},[9]$ ). This program was developed in response to the

72 government's concerns about the benefits that could bring about by the multinationals

73 and has consequently triggered the emergence of new forms of investment as well as

74 international joint-ventures between foreign and Chinese firms in China. The private

75 sector now accounts for more than half of the total industrial output, compared with

76 barely more than a quarter of it in 1998, and it operates much more efficiently than the 
77 public sector (Dougherty et al., [10]). However, in spite of the rapid growth in foreign and domestic non-state investment activities, the share of state ownership in physical capital still predominates in the Chinese economy

80 The net effect of technological progress might depend on the interaction between 81 foreign and indigenous innovations as well as on economic geography. First, foreign 82 and indigenous technology in an economy might interact with each other to create some 83 positive spillovers, e.g., local firms can learn from foreign enterprises. However, 84 competition coming from the presence of foreign companies can also lead to a crowding 85 out effect, since the less productive domestic firms may exit from the market, only the 86 most productive being the ones that survive. Secondly, recent contributions from the 87 economic geography literatures have revealed that the location of economic activity as 88 well as its degree of concentration in the same industry also matter in the process of 89 accumulation of knowledge. Such knowledge spillovers would be higher if the firms are 90 located close to each other and are operating within the same industry and region. 91 Therefore, when explaining the process of knowledge transfer coming from foreign and 92 indigenous innovation in China, geography may play a key role due to the higher 93 concentration of economic activities along the coastal area at the expense of Western 94 regions. Thus, the outcomes from the interaction between foreign and indigenous 95 innovation are, a priori, unclear.

96 In this context, the aim of this work is to provide new insights about three main 97 questions. First, what is the differential role played by foreign and indigenous 98 technology (as well as the interaction between them) on the diffusion of knowledge 99 spillovers with an energy reducing effect? Second, since both location and geography 100 proximity matter in the process of accumulation of knowledge: Are there significant 101 differences in energy efficiency across Chinese regions? Third, is the structure of 
corporate ownership a relevant factor to be considered in explaining the reduction in energy intensity? We examine these issues for all sources of energy in the case of Chinese regions over the period of 2006-2010.

The rest of the paper is organized as follows. Section 2 provides an overview of the literature. Data and methodology are described in Section 3. Results are reported in Section 4, while conclusions are drawn in Section 5.

\section{Literature Review}

Energy efficiency depends on both technological innovations and the accumulation of physical capital. Technological innovations in an economy can come from outside of the country through foreign direct investment and imports or from inside through domestic innovation efforts. First, foreign direct investment plays a double role in the process of energy efficiency improvement. On one hand, it is a potential source of technology transfer and on the other hand it is investment from abroad, which incorporates new technologies into the production process, both of which create knowledge spillovers into the economy (Keller, [11]; Fisher-Vanden et al., [4]; Herrerias et al., [12]; Huber, Error! Reference source not found.; Hübler, [13]; Hübler and Keller, [14]; Kumar, [15]; Ma and Stern, [6]; Perkins and Neumayer, [16]; Sahu and Narayama, [17]). Imports can also affect energy efficiency by stimulating competition between foreign and local firms (Amiti and Konigs, [1]; Herrerias and Orts, [7],). Second, domestic innovation depends, however, on different factors such as the technological capabilities of the home country, investment ownership, the role played by the government in gaining access to foreign technology, as well as local efforts to promote the learning process coming from such technology, among other relevant factors (Audretsch and Feldman, [29]). Thus, countries, especially the developing ones, also have to rely on indigenous innovation efforts to promote economic development 
127 (Fu and Gong, [20]). This capability for domestic innovation seems to play a central

128 role in mastering new technologies and adapting them to local conditions (Lall, [21]). ${ }^{1}$

129 In both sources of technology - foreign and indigenous - the interaction between them

130 and their geographical distribution are relevant factors that should be considered in

131 improving energy efficiency.

132 On the one hand, there are theoretical arguments and empirical evidences have 133 proved that indigenous and foreign innovation efforts can be complementary (Fu et al.,

134 [41]). Such an effect could arise if, for instance, the presence of a multinational can 135 bring knowledge transfer into local firms, which may stimulate both innovation activity 136 and absorptive capacity (Li, [22]; Fisher-Vanden et al., [4]). In addition, information 137 provided by local firms can be very useful as they are more familiar with the local 138 market and the potential of foreign technology (Zhou and Xin, [23]). Positive 139 interactions between foreign and local firms were found by Girma et al. [24], who 140 showed that multinationals played a significant role in restructuring Chinese state141 owned enterprises by introducing new technology and better managerial skills through 142 joint-ventures. While Harrison and Rodriguez-Clare [25] argued that firms with foreign 143 participation in China are of higher level of technology competence. In the case of 144 energy sector, Fu and Zhang [26] illustrated that the simultaneous adoption of both 145 technology transfer and indigenous innovation would be suitable for the technological 146 progress and the development of green technology sectors in developing countries.

147 More recently, however, Sjöholm and Lundin [8] did not find any positive impact of 148 FDI on R\&D in domestically-owned firms, and Perkins and Neumayer [16] argued that 149 increased competitive pressures from multinationals may reduce the profitability of 150 domestic firms and delay their investments in more energy-efficient plants. Moreover,

\footnotetext{
${ }^{1}$ In China, there has been a change in the Chinese government's approach with greater emphasis on indigenous technology development and a more hesitant approach toward FDI (see Sjöholm and Lundin, $[8])$.
} 
151 those domestic firms that are unable to compete on the basis of technology leadership, 152 they might pursue a cost minimization strategy and devote little resource in 153 environment-efficient designs.

154 In this paper, we argue that the mixed evidence about the interaction between foreign 155 and indigenous innovation can be explained by two factors. First, spillovers associated 156 with both foreign transactions and indigenous innovation capabilities might be 157 geographically localized (Jaffe et al., [27]). Second, empirical evidence indicates that 158 innovation capabilities seem to vary by type of ownership. In the case of China, Wang 159 and Lin [28] recently emphasized the need to account for both regional factors and firm160 level characteristics in order to analyze the dynamics of innovation.

161 On the other hand, the literature on knowledge spillovers and the geography of 162 innovation highlights the fact that geography matters in transmitting knowledge 163 (Audretsch and Feldman, [29]). Proximity enhances the ability of firms to exchange 164 ideas thereby allowing them to increase the accumulation of knowledge, and reducing 165 the uncertainty in the market where they operate. For these firms, being spatially 166 concentrated in areas where resources are abundant reduces the cost of scientific 167 discoveries and commercialization (Feldman, [30]). However, empirical evidence 168 suggests that these knowledge externalities are higher when firms are located in similar 169 industries and geographically concentrated areas (Audretsch and Feldman, [19], Xu and 170 Sheng, [31]; Girma and Gong, [32]; Girma et al., [24]; Ivarsson and Alvstam, [33]; 171 Sjöholm and Lundin, [8]).

172 Regarding the implications of ownership structure, Du et al. [34] highlighted the 173 extraordinarily heterogeneous ownership structure in $\mathrm{China}^{2}$ and argued that indigenous 174 Chinese firms of different ownership behaved differently with respect to imitation,

\footnotetext{
${ }^{2}$ See Figure 1.
} 
175 innovation and competition, and displayed different technological capabilities for 176 knowledge absorption from the presence of foreign firms. Jefferson et al. [35] found 177 that ownership diversification during the period 1994-1999 led to the emergence of 178 high-intensity R\&D performers that exhibited substantial innovation capabilities. They 179 further argued that foreign, private, and share-holding enterprises are the ones that made 180 the greatest innovation efforts in China. In similar terms, Girma et al. [42] concluded 181 that private and collectively-owned firms with foreign capital participation tended to 182 innovate more than other types of ownership. In the case of energy sector in China, 183 Fisher-Vanden et al. [3] found that ownership reform in the enterprise sector is one of 184 the principal drivers of China's declining energy intensity. Their results found that 185 foreign-invested firms were consistently more energy-efficient than their state-owned 186 counterparts. Sinton and Fridley [36] concluded that the shift from state-owned to 187 collective, private, and foreign-invested ownership has played an important role in 188 improving energy efficiency in China since 1996. Recently, Herrerias et al. [12] pointed 189 out that both foreign and non-state investments had played a leading role in the decline 190 of energy intensity across 28 Chinese regions, whereas no evidence of a positive 191 contribution of the state investment was identified. However, that work ignores 192 indigenous innovation and the different types of investment ownership that operate 193 through the transmission grids. This paper fills this gap in the relevant literature.

194 3. Data and Methodology

\subsection{Data}

196 This paper investigates the role played by both foreign and indigenous innovation as 197 key mechanisms to reduce energy intensity as well as the structure of investment 198 ownership in China over the period of 2006-2010. In doing so, the foreign technology is 199 measured by foreign direct investment and imports, while indigenous innovations are 
captured by patents. In addition, we disaggregate total investment in fixed assets into

state-owned, collectively-owned, cooperative, joint-venture, limited liability, share-

holding, private, self-employed, and foreign investment, which are measured as percentages of GDP. This disaggregation provides a complete picture of this phenomenon and its relevance to the study of energy intensity across 30 Chinese regions. FDI, imports ${ }^{3}$ and the number of patents have been included to separate the effect of foreign innovation from that of domestic innovation. Patents can be regarded as a good reflection of indigenous innovation efforts as they usually contain technological improvements and/or innovative ideas that at least have to be new in the country. Therefore, these variables are associated with the aforementioned technique effect. We investigate not only total energy intensity (Total energy consumption/GDP), but also other relevant sources of energy such as coal, electricity, petroleum, and natural gas. These too are expressed in intensities.

To provide robust estimates, other control variables such as the share of industry ${ }^{4}$ 214 (expressed as share of GDP) and energy prices (electricity and oil prices) are also 215 included. The share of industry is related to the composition effect, while an increase in 216 energy prices is an additional factor that may reduce energy intensity (Zhao et al., [37]; $217 \mathrm{Wu},[38])$. Since the progressive liberalization of the pricing system, the increase in 218 energy prices has led to a reduction in energy consumption, thereby improving the 219 energy intensity ratio (Fisher-Vanden et al., [3]; Herrerias et al., [12]). In the case of the 220 Chinese economy, information about energy prices is rather limited. To overcome this problem, we use electricity price for total energy, coal, and natural gas intensity, while oil price is used for oil intensity. We are aware of the drawbacks of this procedure but,

\footnotetext{
${ }^{3}$ We have introduced imports into the analysis since, on average, capital goods represented around $70 \%$ of the overall imports over the period 1962-2004. See Herrerias and Orts [7].

${ }^{4}$ Given the lack of data, we cannot disaggregate this variable in greater detail at the provincial level in China.
} 
223 at the moment, it is the only information available in the Chinese statistics. The source 224 of data is from the National Bureau of Statistics of China (NBS). ${ }^{5}$

225 As been mentioned above, taking the Chinese regional dimension into account is 226 essential. In this paper, we employ two different approaches to deal with regional 227 heterogeneity. The first is based on the inclusion of a set of dummy variables in the case 228 of those provinces that belong to each of the six transmission grids that exist in China 229 (see Figure 3). We then make an interaction effect of this dummy variable with each of 230 the ownership structure considered in this work. This allows us to investigate the 231 differential effect by type of ownership across different transmission grids. The second 232 approach to overcome the heterogeneity of the Chinese provinces is to estimate the 233 model allowing for heteroskedasticity.

234 Tables 1 and 2 provide a summary of statistics of investment ownership and energy 235 intensity variables. From there, we can observe that state-ownership predominates over 236 other types of investment, even in a period that is characterized by a process of 237 liberalization. The period (2006-2010) was not chosen at random, but rather it attempts 238 to capture the period of time when most of the reforms took place. Moreover, since 2392006 Chinese statistics offer a more detailed view of this investment structure, with 240 improved information coming from the NBS. Prior to 2006, part of the investment was 241 classified as "other types of investment", without knowing what type of investment it 242 belonged to. With this change, we have a clearer picture of each type of investment 243 ownership. In fact, there is a growing trend for domestic investment to take the form of 244 private and limited liability $(10.3 \%$ and $15.1 \%$ respectively on average for the period 245 under consideration), and also share-holding investment reaches $27.9 \%$ in some regions,

\footnotetext{
${ }^{5}$ See Data Appendix for a detailed description of each variable.
} 
even though on average it represents only $4 \%$ of the ownership. ${ }^{6}$ This is not unusual,

given the aforementioned heterogeneity, as shown in Figure 1 (a-i). It plots each type of investment ownership on a map of the Chinese regions in 2010. Table 2 shows information about energy intensity for both total and each source of energy considered.

We can see that oil displays the highest percentage (16.4\%), and it is relatively close to the more traditional sources of energy used by China, like coal and electricity $(14.1 \%$ and $13.7 \%)$.

\subsection{Methodology}

254 Panel data methods were applied in order to consider the heterogeneity of Chinese regions over time. Within the battery of estimators available, we selected the one proposed by Beck and Katz [39], the so-called panel-corrected standard errors. The attractiveness of this approach, according to these authors, is that common techniques applied to time-series cross-section (TSCS) data produce incorrect results, in particular with regard to the accuracy of the standard errors.

260 It is well-known that OLS becomes problematic in panel data techniques, when one or more Markov assumptions are not satisfied. In the presence of temporal and spatial correlation in the error term as well as heteroskedasticity, Parks [40] proposed a method to deal with these problems based on GLS. However, the use of this method can lead to 264 dramatic underestimates of parameter variability in common research due to the 265 assumptions made about the structure of the error term, such as it is known. The alternative often used by researchers is to apply the Feasible Generalized Least Squares (FGLS), which relaxes the assumption of the known errors structure and uses estimates

\footnotetext{
${ }^{6}$ Another reason for considering this time period for the analysis is the fact that we aim to investigate the effect of both foreign and indigenous technology on energy intensity. However, the latter has become relevant since the People's Party Congress in 2006, where the focus of the Five-Year Plan relied on technology development. The ambition was to make the People's Republic of China an innovation-driven economy. We are aware of the short sample for the analysis, and therefore results should be interpreted with caution.
} 
of the error process. However, when there are a large number of parameters to estimate,

269 FGLS causes estimates of the standard errors of the estimated coefficients to understate

270 their true variability by between $50 \%$ and $300 \%$, according to Monte Carlo simulations

271 (Beck and Katz, [39]). To solve the apparent problem, Beck and Katz [39] suggested

272 correcting the formula for the sampling variability of the OLS estimates, which is given

273 by the square roots of the diagonal term.

274 Thus, the standard formulation of TSCS models under the assumption of poolability 275 is as follows: ${ }^{7}$

$$
y_{i t}=X_{i t} \beta+\lambda_{i}+\gamma_{t}+\epsilon_{i j} \quad i=1, \ldots N ; t=1 \ldots T
$$

$$
\epsilon_{i, t}=\rho_{i} \epsilon_{i, t-1}+v_{i, t}
$$

where $\boldsymbol{X}_{i t}$ is a vector of $k$ exogenous variables, and observations are indexed both by

unit $(i)$ and by time $(t){ }^{8} y_{i t}$ denotes the vector of observations on the dependent

variable, $\lambda$ and $\gamma$ are individual and time effects respectively and $v_{i, t}$ are variables that are independently distributed over time. Thus, Parks' method, which is based on FGLS,

takes into account panel heteroskedasticity and unit-specific serial correlation $\left(\rho_{i}\right)$.

\section{Results}

In Table 3, we present the results for each type of investment ownership as well as

for imported technology, and their effects on energy intensity for both total energy and the different sources of energy considered in this work. In Table 4, besides the structure of investment, we also account for the effect of indigenous innovation. Tables 5 and 6 present the results of the relationship between foreign and indigenous innovation on energy intensity. Finally, Table 7 shows a summary of the results coming from the

\footnotetext{
${ }^{7}$ Given the small sample in our data, the issue of heterogeneity in the beta coefficient is not considered. In addition and for the same reason, we only contemplate the static version of the panel data.

${ }^{8}$ We tested for endogeneity in all our estimated models. However, we did not find any symptoms of this problem, thereby making the application of instrumental variables unnecessary. Furthermore, due to the small sample and unbalanced panel, panel cointegration techniques were not applied. This method requires a longer period to obtain robust estimates.
} 
spatial dimension. ${ }^{9}$ The first four columns of these tables report the results for "Total

291 Energy Intensity", while the others show the findings for "Coal", "Electricity", "Gas", 292 and "Oil" intensity.

293 Recall that the technique effect is captured by both foreign and indigenous 294 innovation. The foreign technology is comprised with FDI and imports, while 295 indigenous innovations are represented by patents. According to our results (Table 3 296 and 4), both foreign and indigenous technology matter in the process of energy 297 efficiency improvement. However, this effect could be influenced by the source of energy under consideration in the case of foreign technology. On the one hand, our 299 findings show that foreign investment ${ }^{10}$ could reduce total energy intensity and coal intensity. This is explained by the fact that China is coal dependent and also because the coal industry was among the first energy sectors opened up for foreign entry with the aim of bringing in advanced expertise and technology. On the other hand, imports improve total energy efficiency in China as well as for the electricity sector. The knowledge transfer through openness seems to play an important role in this industry. In addition, the electric power cuts in the majority of regions during the summer period, and the need to import energy from abroad, can partially explain these results.

The effect of indigenous innovation is reported in Table 4. As can be observed, patents are always significant and with a negative sign. ${ }^{11}$ These findings indicate that compared with technology transfer via FDI and imports, domestic innovation seems to play a more significant role in the diffusion of energy-saving technologies. This is consistent with the finding of $\mathrm{Fu}$ and Gong [20] that indigenous technology may result

\footnotetext{
${ }^{9}$ Appendix A reports the complete statistical results for each type of investment ownership.

${ }^{10}$ We are aware that other types of ownership might contain some foreign participation Jointly with the domestic one. However, we are not able to distinguish the percentage of foreign participation due the lack of data. Thus, for the sake of simplicity we attribute the technique effect to foreign investment and imports.

${ }^{11}$ We have to keep in mind that most of the patents still come from the state sector (see Fu and Gong, 2011; Li, 2011).
} 
312 in higher efficiency gains in certain sectors. Li [22] further argues that to use foreign 313 technology better, China should enhance its absorptive capacity through its own R\&D 314 activities.

315 An interesting hypothesis to be tested is the relationship between foreign and 316 indigenous technology, and energy intensity. In doing so, we define an interaction effect 317 that is the product of foreign direct investment and patents (Table 5), and then we define 318 another one that is the product of imports and patents (Table 6). This empirical strategy 319 allows us to distinguish the two components of our foreign technical effects and their 320 relation with indigenous innovation. Our results show that the combination of foreign 321 and domestic technology as drivers of energy-saving measures only matters with regard 322 to total and coal intensity. By contrast, it seems that foreign and indigenous innovations 323 have a crowding-out effect on oil energy intensity. The limited impact of the interaction 324 between foreign and domestic technology in China is also found in Sjöholm and Lundin, 325 [8]. One of the possible explanations for this outcome is the long adaption process of 326 foreign technology by domestic firms and the lack of coordination among the different 327 stakeholders (Karplus, [42]). In addition, as previously mentioned, the spillovers can 328 have certain effect within the same industry or region, but no effect across regions.

329 As can be observed in Tables 3 and 4, when it comes to explain the evolution of 330 energy intensity across Chinese regions, the type of investment ownership matters. 331 Empirical results from Tables 3 and 4 show that state investment does not seem to help 332 in the reduction of energy intensity in any case since, as whenever significant, it shows 333 a positive sign. This effect is more evident among the Northern and Central provinces in 334 China in the case of coal and electricity intensity (Table 7). These results are similar to 335 the ones obtained by Sinton and Fridley [36] and Herrerias et al. [12] for China. These 336 studies confirm that a shift from state-owned investment plays a key role in improving 
energy efficiency in this country. Among non-state investments, there are notable

differences for each type of investment, geographical transmission grid and source of energy. We find that both self-employed and foreign investments ${ }^{12}$ are beneficial to improve total energy efficiency (Tables 3 and 4). However, only the latter shows a significant effect in the East, North and South of China (Table 7). In the case of coal, in

342 addition to foreign investment, share-holding investment is also found to play a 343 significant role in reducing coal intensity, especially in the Southern provinces (Table 344 7). The role played by share-holding investment on coal intensity is robust to different specifications (Table 4) and can be explained by its significant participation in this 346 industry. For electricity intensity, we find that only private investment has a significant 347 negative influence. Once the economic geography is taken into account, we observe that 348 this phenomenon is concentrated in the North-East of China (Table 7). This result can 349 be explained by the dominant presence of the state sector in the electricity market. In the 350 case of gas and oil intensity, cooperative, self-employed, joint-ventures, and private investments are useful conduits for the improvement of gas efficiency resources (Tables 3523 and 4). Cooperative investment has a major impact in the North-East of China, while 353 self-employed, joint-ventures and private investments seem to be more significant in the 354 North-East, East and South of China (Table 7). However, in the case of oil intensity, 355 cooperative investment appears to be significant in Central regions, while the effects for 356 self-employed, joint-ventures and private investments predominate more in the North, 357 Central and South, except in private investments that are also relevant in the Eastern 358 area.

359 These results could be explained by the fact that the National Development and 360 Reform Commission (NDRC) is making all-out efforts to encourage private investment

\footnotetext{
${ }^{12}$ Kumar [15] and Sahu and Narayama [17] for India and Fisher-Vanden et al. [3][4] for China confirm that foreign companies are more efficient in the use of energy resources than their domestic counterparts.
} 
361 in more heavily state-controlled and monopolized sectors, such as electricity, oil, and 362 natural gas, in order to make the economy more dynamic and to reduce the presence of 363 the state sector. Moreover, in recent years, the Chinese government has invited foreign 364 joint-ventures to bid for shale gas exploration licenses to develop China's potential 365 reserves and to mitigate its dependence on imported coal and oil. Relatively recent 366 infrastructure projects like the West-East Electricity Transfer Project that aims to 367 increase the generation capacity in Northern and Central provinces and the "West-to368 East Gas Transmission Pipe Line" in the Southern and Eastern areas would help to 369 improve the efficiency of energy resources. This strategy can allow China to become 370 more self-sufficient in energy.

371 The above-mentioned results give support to the so-called technical effect, and 372 highlight the importance of the reforms in the structure of investment ownership as well 373 as the need to strength both domestic and foreign innovation in order to improve energy 374 efficiency in China. In all the specifications, the composition effect, captured by the 375 share of the secondary sector over GDP, shows the expected sign, namely, in all the 376 cases where it is significant, industry has a positive sign, except in gas intensity. This 377 result indicates that further improvements in energy intensity can be achieved through 378 sectoral decomposition, for example by shifting toward less energy-intensive sectors. 379 The Chinese economy depends on industrial performance which consumes a significant 380 amount of coal. The increasing relevance of the service sector is a challenge to balance 381 the economy for the sustainability of regional growth and a better use of energy 382 resources.

383 Finally, Chinese energy prices are found to be an additional source of improvement 384 in the use of energy resources per unit of output across regions in the case of total 385 energy intensity, gas, and coal intensity when imports are included in the model as a 
source of technological transfer (Table 3), and total energy intensity and coal intensity

when domestic innovations are considered (Table 4). However, we found that in oil intensity, oil prices are not significant (Tables 3 and 4) and in electricity intensity its price has a positive sign. These unexpected findings might indicate that a liberalization of energy prices in China could improve energy efficiency, and therefore further reforms are required in this sector. ${ }^{13}$

\section{Conclusions}

Suitable policies for the improvement of energy efficiency in China have received considerable attention among economists and policy-makers owing to their significant implications for climate change and environmental protection. Changes in energy intensity can be attributed to both technological progress and industrial composition. However, a limited number of studies have identified the precise channels through which these effects may operate.

In this paper, we argue that both indigenous and foreign innovations play an important role in the diffusion of knowledge spillovers with an energy-reducing effect in this country. However, this externality may vary depending on both of the structure of the investment as well as its geographical location. Our findings corroborate the importance of accounting for these two factors when analyzing the dynamics of energy 404 intensity in China. The fact that geography matters in the process of transmission of 405 knowledge is not surprising due to the high level of heterogeneity in the regional 406 distribution of economic activity and the uneven distribution of the different types of 407 firms across China. To the best of our knowledge, this is the first paper to address this question.

\footnotetext{
${ }^{13}$ See Herrerias et al. [12], where it is found that international crude oil price is an additional factor in reducing energy intensity with different specifications.
} 
Our empirical analysis is performed across 30 Chinese regions over the period of 410 2006-2010 by using panel data techniques. The results obtained suggest, on one hand, 411 that both domestic and foreign technology play an important role in improving the use 412 of energy resources. However, the former seems to play a leading role in such process.

413 In addition, the interaction between foreign and domestic technology to improve energy 414 efficiency is quiet modest, indicating the need to promote not only both foreign and 415 indigenous technology, but also to create the mechanisms in domestic firms that can 416 facilitate the assimilation and implementation of foreign technology in their production 417 process. On the other hand, our estimates indicate that the specific type of investment 418 ownership matters when it comes to explain the reduction in energy intensity. We find 419 that state investment plays a minor role in reducing any source of energy intensity in 420 China. Non-state investment is, by far, a more important element. More specifically, we 421 find that private investment plays an important role in this process in all sources of 422 energy except in coal intensity. Cooperative and joint-ventures seem to be significant in 423 reducing gas and oil intensity, while share-holding investment reduces mainly coal 424 intensity. Foreign investment seems to be relevant for total and coal energy intensity. 425 However, once we consider the regional heterogeneity and we estimate the differential 426 effect of investment ownership, we observe that most of the non-state investment has 427 greater effects in the Eastern and Southern provinces when compared with the Central 428 and Western ones. For the vast North and Western regions, limited progress has been 429 made in improving all sources of energy efficiency among various ownership structures. 430 This is partially because of the state's dominant position in these regions and partially 431 because of their relatively affluent reserves of resources. Hence, according to our 432 results, what matters in reducing energy intensity is not only the type of investment 433 ownership, but also its geographical location. 
Finally, the share of industry (which captures the composition effect) is mainly

positive, thereby indicating that there is much room for improvement in the use of

energy resources by promoting changes in the sectorial composition. We also find that,

437 in most of the cases, increases in energy prices reduce energy intensity.

438 To sum up, energy policies that aim to promote foreign and domestic innovations as 439 well as an increase in the presence of the non-state sector across the Chinese provinces 440 may improve energy efficiency, thereby contributing to environmental protection both 441 in China and worldwide.

444 [1] Herrerias, M.J., Joyeux, R. and Girardin, E. Short- and Long-run Causality 445 Between Energy Consumption and Economic Growth: Evidence Across Regions 446 in China. Applied Energy 2013b:112:1483-1492.

447 [2] Zhang, Z. Why did the energy intensity fall in China's industrial sector in the

\section{References} 1990s? The relative importance of structural change and intensity change, Energy Economics 2003:25:625-638

[3] Fisher-Vanden, K., Jefferson, G. Liu, H. and Tao, Q. What is driving China's decline in energy intensity? Resource and Energy Economics 2004:26:77-97.

[4] Fisher-Vanden, K., Jefferson, M. Jingkui, and Jianyi, X. Technology development and energy productivity in China, Energy Economics 2006:28:690-705.

[5] Liao, H., Fan, Y. and Wei, Y. What induced China's energy intensity to fluctuate: 1997-2006? Energy Policy 2007:35:4640-4649

[6] Ma, C. and Stern, D. China's Changing Energy Intensity Trend: a Decomposition Analysis. Energy Economics 2008:30:1037-1053

[7] Herrerias M.J. and Orts, V. Imports and Growth in China. Economic Modeling 2011:28:2811-2819 
460 [8] Sjöholm, F. and Lundin, N. Foreign Firms and Indigenous Technology

461 Development in the People's Republic of China. Asian Development Review $462 \quad 2013: 30: 49-75$.

463 [9] Jefferson, G. and Su, J. Privatization and Restructuring in China: Evidence from 464 Shareholding Ownership, 1995-2001. Journal of Comparative Economics $465 \quad 2006: 34: 146-166$

466 [10] Dougherty, S., Herd, R. and He, P. Has a private sector emerged in China's 467 industry? Evidence from a quarter of a million Chinese firms, China Economic $468 \quad$ Review 2007:18:309-334.

469 [11] Keller, W. International Technology Diffusion. Journal of Economic Literature $470 \quad$ XLII, 2004:752-782.

471 [12] Herrerias, M.J., Cuadros, A. and Orts, V. Energy Intensity and Investment 472 ownership across Chinese Provinces. Energy Economics 2013a:36:286-298

473 [13] Hübler, M. Technology Diffusion under Contraction and Convergence: A CGE Analysis of China. Energy Economics 2011:33:131-142.

[14] Hübler, M. and Keller, A. Energy Savings via FDI? Empirical Evidence from Developing Countries. Environment and Development Economics 2010:15:59-80.

[15] Kumar, A. Energy Intensity: A Quantitative Exploration for Indian Manufacturing. Indira Gandhi Institute of Development Research, Mumbai 2003:65

[16] Perkins, R. and Neumayer, E. Transnational Linkages and the Spillover of Environment-Efficiency into Developing Countries. Global Environment Change 2009:19:375-383.

483

[17] Sahu, S. and Narayanan, K. Determinants of Energy Intensity: A preliminary investigation of Indian manufacturing. MPRA Paper No. 16606, August 2009 
485 [18] Amiti, M. and Konings, J. Trade liberalization, intermediate inputs and productivity: evidence from Indonesia. The American Economic Review 2007:97: $1611-1638$

[19] Audretsch, D. and Feldman, M. R\&D Spillovers and the Geography of Innovation and Production. American Economic Review 1996:86:(4):253-273.

[20] Fu, X. and Gong, Y. Indigenous and Foreign Innovation Efforts and Drivers of Technological Upgrading: Evidence from China. World Development 2011:39: 1213-1225

[21] Lall, S. Technological Capabilities and Industrialization. World Development 1992:20:165-186.

[22] Li, X. Sources of External Technology, Absorptive Capacity, and Innovation Capability in Chinese-Owned High-Tech Enterprises. World Development 2011:39:1240-1248.

[23] Zhou, Y. and Xin, T. An Innovative Region in China: Interaction Between Multinational Corporations and Local Firms in a High-Tech Cluster In Beijing. Economic Geography 2003:79:129-152.

[24] Girma, S., Gong, Y. and Görg, H. What Determines Innovation Activity in Chinese State-owned Enterprises? The Role of Foreign Direct Investment. World Development 2009:37:866-873.

[25] Harrison, A. and Rodriguez-Clare, A. Trade, FDI and Industrial Policy for Developing Countries. Handbook of Development Economics vol. 5, Chapter 63 2010:4039-4124.

[26] Fu, X. and Zhang, J. Technology Transfer, Indigenous Innovation and Leapfrogging in Green Technology: the Solar-PV Industry in China and India. Journal of Chinese Economic and Business Studies 2011:9:329-347. 
[27] Jaffe, A., Trajtenberg, M. and Henderson, R. Geographic Localization of Knowledge Spillovers as Evidenced by Patent Citations. Quarterly Journal of Economics 1993:63:577-598.

[28] Wang, C. and Lin, G. Dynamics of Innovation in a Globalizing China: Regional Environment, Inter-Firm Relations and Firm Attributes. Journal of Economic Geography 2013:13:397-418.

[29] Audretsch, D. and Feldman, M. Knowledge Spillovers and the Geography of Innovation. Handbook of Regional and Urban Economics, vol. 4. Elsevier 2004.

[30] Feldman, M. The Geography of Innovation. Kluwer Academic, Boston 1994.

[31] Xu, X. and Sheng, Y. Are FDI Spillovers Regional? Firm-Level Evidence from China. Journal of Asian Economics 2012:23:244-258.

[32] Girma, S. and Gong, Y. FDI, Linkages and the efficiency of State Owned Enterprises in China. Journal of Development Studies 2008:44:728-749.

[33] Ivarsson, I. and Alvstam, C. The Effects of Spatial Proximity on Technology Transfer from TNCs to Local Suppliers in Developing Countries: The Case of AB Volvo in Asia and Latin America. Economic Geography 2005:81:83-111.

[34] Du, L., Harrison, A. and Jefferson, G. Do Institutions Matter for FDI Spillovers? The Implications of China's Special Characteristics. Working Paper 16767, National Bureau of Economic Research 2011.

[35] Jefferson, G., Hu, A., Guan, X. and Yu, X. Ownership, Performance and Innovation in China's Large-and Medium Size Industrial Enterprise Sector. China Economic Review 2003:14:89-113.

[36] Sinton, J. and Fridley, D. What Goes Up: Recent Trend in China's Energy Consumption. Energy Policy 2000:28:671-687. 
534 [37] Zhao, X., Ma, C. and Hong, D. Why Did China's Energy Intensity Increase

535 During 1998-2006: Decomposition and Policy Analysis. Energy Policy $536 \quad 2010: 38: 1379-1388$.

537 [38] Wu, Y. Energy Intensity and Its Determinants in China's Regional Economies, $538 \quad$ Energy Policy 2012:41:703-711

539 [39] Beck, N. and Katz, J. (). What to do and not to do with Time-Series Cross-Section 540 Data, The American Political Science Review 1995:89:634-647.

541 [40] Parks, R. Efficient Estimation of a System of Regression Equations When 542 Disturbances Are Both Serially and Contemporaneously Correlated. Journal of $543 \quad$ American Statistical Association 1967:62:500-509.

544 [41] Fu, X., Pietrobelli, C. and Soete, L. The Role of Foreign Technology and 545 Indigenous Innovation in the Emerging Economies: Technology Change and $546 \quad$ Catching Up. World Development 2011:39:1204-1212.

547 [42] Karplus, V. J. (), Innovation in China's energy sector, Working Paper for the 548 program on energy and Sustainable Development, Centre for Environmental $549 \quad$ Science and Policy, Stanford University 2007.

550

551 


\section{Data Appendix}

GDP: Gross Regional Product (100 Million Yuan). This refers to the final products at market prices produced by all resident units within a country (or a region) over a certain period of time.

Industry: Secondary Industry/GDP. This refers to mining and quarrying, manufacturing, production and supply of electricity, water and gas, and construction.

Energy Intensity Total: This refers to the total energy consumption in each region divided by GDP.

Energy Intensity Coal: This refers to coal consumption divided by GDP.

Energy Intensity Electricity: This refers to electricity consumption divided by GDP.

Energy Intensity Petroleum: This refers to oil consumption divided by GDP.

Energy Intensity Natural Gas: This refers to natural gas consumption divided by GDP.

Patent (Number of Applications Accepted and Granted): This is an abbreviation for the patent right and refers to the exclusive right of ownership by the inventors or designers of the creation or inventions, which is issued by the patents office after the due process of assessment and approval in accordance with Patent Law. Patents are granted for inventions, utility models, and designs. This indicator reflects the achievements of S\&T and design with independent intellectual property.

Imports (IMP/GDP): This refers to the real value of commodities imported across the borders of China. They include the actual imports through foreign trade, goods imported for the processing and assembly trades, and materials, supplies and gifts as aid given gratis between both governments and the United Nations and other international organizations, as well as contributions donated by overseas Chinese, compatriots in Hong Kong and Macao and Chinese with foreign citizenship, leasing commodities owned by tenants on expiry of the leasing period, imported commodities processed with imported materials, commodities trading in border areas (excluding mutual exchange goods), the imported commodities and articles for public use of the Sino-foreign Joint ventures, cooperative enterprises, and ventures with sole foreign investment. The indicator of the total imports at customs can be used to observe the total size of external trade in a country. In accordance with the stipulation of the Chinese government, imports are calculated CIF. We divided imports by GDP.

Price: We use electricity price (for Industry $35 \mathrm{kV}$ and above, $\mathrm{RMB} / \mathrm{KWH}$ ) and Oil price (RMB/Ton), which is the only information available. In the case of total energy consumption, coal consumption, and natural gas, we use electricity price as a proxy variable.

\section{Investment Ownership: (Investment ownership / GDP)}

State-owned: This refers to non-corporation economic units where the entire assets are owned by the State and which have registered in accordance with the Regulation of the People's Republic of China on the Management of Registration of Corporate 
594 Enterprises. Excluded from this category are sole state-funded corporations in the 595 limited liability corporations.

596 Collective-owned: This refers to economic units where the assets are owned 597 collectively, and which have registered in accordance with the Regulation of the 598 People's Republic of China on the Management of Registration of Corporate 599 Enterprises.

600 Cooperative: This refers to a form of collective economic units (enterprises) where 601 capitals come mainly from employees as their shares, with a certain proportion of 602 capital from the outside, where production is organized on the basis of independent 603 operation, independent accounting for profits and losses, Joint work, democratic 604 management, and a distribution system that integrates remuneration according to work with a dividend according to capital share.

Joint-Venture: This refers to economic units established by two or more corporate enterprises or corporate institutions of the same or different ownership, through Joint investment on the basis of equality, voluntary participation, and mutual benefits. They include state Joint-ownership enterprises, collective Joint-ownership enterprises, Joint state-collective enterprises, and other Joint-ownership enterprises.

Limited Liability: This refers to economic units established with investment from 250 investors and registered in accordance with the Regulation of the People's Republic of China on the Management of Registration of Corporations, each investor bearing limited liability to the corporation depending on its share of investment, and the corporation bearing liability to its debt to the maximum of its total assets. Limited liability corporations include exclusive state-funded limited liability corporations and other limited liability corporations.

Share-holding: This refers to economic units registered in accordance with the Regulation of the People's Republic of China on the Management of Registration of Corporations, with total registered capitals divided into equal shares and raised through issuing stocks. Each investor bears limited liability to the corporation depending on the holding of shares, and the corporation bears liability to its debt to the maximum of its total assets.

Private: This refers to profit-making economic units invested and established by natural persons, or controlled by natural persons using employed labor. Included in this category are private limited liability corporations, private share-holding corporations Ltd., private partnership enterprises, and private-funded enterprises registered in accordance with the Corporation Law, Partnership Enterprises Law, and Interim Regulations on Private Enterprises.

Self-employed Individual: This refers to domestic-funded economic individuals other than those mentioned above.

Foreign Funded: This refers to enterprises established in the mainland of China with exclusive investment from foreign investors in accordance with the Law of the People's Republic of China on Foreign-Funded Enterprises and other relevant laws.

Source: All definitions come from the National Bureau of Statistics of China in their original form. 
Table 1: Summary of Statistics, Investment Ownership / GDP. (2006-2010)

\begin{tabular}{lccccc}
\hline Variable & Obs. & Mean & Std. Dev. & Min & Max \\
\hline State & 150 & 0.193 & 0.077 & 0.064 & 0.409 \\
Collective & 150 & 0.015 & 0.013 & 0.000 & 0.061 \\
Cooperative & 150 & 0.003 & 0.002 & 0.000 & 0.010 \\
Joint & 150 & 0.002 & 0.002 & 0.000 & 0.010 \\
Limited & 150 & 0.151 & 0.057 & 0.056 & 0.334 \\
Share-holding & 150 & 0.044 & 0.023 & 0.009 & 0.145 \\
Private & 150 & 0.103 & 0.057 & 0.017 & 0.279 \\
Self-employed & 150 & 0.025 & 0.012 & 0.000 & 0.067 \\
Foreign & 150 & 0.020 & 0.014 & 0.003 & 0.058 \\
\hline
\end{tabular}

Table 2: Summary of Statistics, Energy Consumption / GDP (2006-2010)

\begin{tabular}{lccccc}
\hline Variable & Obs. & Mean & Std. Dev. & Min & Max \\
\hline Total Energy & 120 & 0.134 & 0.064 & 0.054 & 0.398 \\
Coal Energy & 120 & 0.141 & 0.110 & 0.022 & 0.602 \\
Electricity Energy & 120 & 0.137 & 0.082 & 0.062 & 0.532 \\
Oil Energy & 112 & 0.164 & 0.160 & 0.000 & 0.667 \\
Natural Gas Energy & 120 & 0.005 & 0.006 & 0.000 & 0.023 \\
\hline
\end{tabular}

643

\begin{tabular}{|c|c|c|c|c|c|}
\hline & Total & Coal & Electricity & Gas & Oil \\
\hline State & $0.3550 * * *$ & 0.9030 & $0.1780 *$ & 0.0052 & -0.1040 \\
\hline Collective & 0.4374 & 0.4227 & 0.3440 & 0.0518 & 0.1550 \\
\hline Cooperative & 0.2131 & $0.6070 * *$ & $0.3917 *$ & $-0.2750 *$ & $-0.7700 * *$ \\
\hline Joint & 0.1938 & $0.8604 * *$ & 0.9180 & $-0.1920 *$ & $-0.1449 * * *$ \\
\hline Limited & 0.5850 & $0.5366^{* * *}$ & 0.0941 & 0.0172 & 0.2420 \\
\hline Share-holding & $0.2435^{*}$ & $-0.6232 * * *$ & 0.3140 & $0.1050 * * *$ & $0.3872 * * *$ \\
\hline Private & $-0.1797 * *$ & -0.1010 & $-0.3050 * * *$ & $-0.0374 * * *$ & $-0.1192 * * *$ \\
\hline Self-employed & $-0.6551 * * *$ & -0.1084 & -0.3520 & -0.0495 & $-0.1825 * *$ \\
\hline Foreign & $-0.6905 * *$ & $-0.1902 * * *$ & 0.0175 & 0.0174 & 0.2285 \\
\hline Industry & $0.2223 * * *$ & $0.4814 * * *$ & $0.3190 * * *$ & $-0.0165 *$ & 0.1810 \\
\hline Imports & $-0.3650 * * *$ & -0.1580 & $-0.0314 *$ & -0.0002 & 0.0769 \\
\hline Electricity Price & $-0.8650 * * *$ & $-0.3025^{* * *}$ & $0.0279 * *$ & $-0.0068 * *$ & \\
\hline Oil Price & & & & & -0.0605 \\
\hline No observations & 120 & 120 & 120 & 120 & 112 \\
\hline $\mathrm{R}^{2}$ & 0.9592 & 0.9287 & 0.9646 & 0.8493 & 0.8843 \\
\hline Individual Effects & Yes & Yes & Yes & Yes & Yes \\
\hline Time Effects & Yes & Yes & Yes & Yes & Yes \\
\hline
\end{tabular}

Table 3: Investment Ownership, imported technology, and energy intensity 
Table 4: Investment Ownership, domestic innovation, and energy intensity

\begin{tabular}{|c|c|c|c|c|c|}
\hline & Total & Coal & Electricity & Gas & Oil \\
\hline State & $0.2812 * * *$ & 0.7460 & $0.2140 * *$ & $0.0144 * *$ & -0.1540 \\
\hline Collective & 0.3861 & 0.5747 & 0.3030 & 0.0192 & 0.1130 \\
\hline Cooperative & 0.1976 & $0.4914 * *$ & $0.5121 * * *$ & $-0.3140 * *$ & $-0.8483 * *$ \\
\hline Joint & 0.1315 & $0.7926^{* *}$ & 0.0063 & -0.0975 & $-0.1289 * * *$ \\
\hline Limited & 0.2570 & $0.4847 * * *$ & -0.0175 & 0.0036 & -0.0066 \\
\hline Share-holding & 0.2680 & $-0.5945^{* *}$ & 0.0919 & $0.0899 * * *$ & $0.3601 * * *$ \\
\hline Private & -0.9180 & -0.0782 & -0.1630 & $-0.0259 * *$ & $-0.1031 * * *$ \\
\hline Self-Employed & $-0.5491 * *$ & -0.1317 & -0.4040 & $-0.0933 * *$ & $-0.1893 * *$ \\
\hline Foreign & $-0.7527 * *$ & $-0.1756 * * *$ & 0.0808 & 0.0441 & $0.3314 * *$ \\
\hline Industry & $0.3522 * * *$ & $0.5479 * * *$ & $0.4160 * * *$ & -0.0104 & 0.2200 \\
\hline $\begin{array}{l}\text { Patents } \\
\text { Electricity }\end{array}$ & $-0.1560 * * *$ & $-0.1010 *$ & $-0.0207 * * *$ & $-0.0020 * * *$ & $-0.0302 * *$ \\
\hline Price & $-0.7070 * * *$ & $-0.2603 * * *$ & 0.0456 & -0.0032 & \\
\hline Oil Price & & & & & 0.0079 \\
\hline $\begin{array}{l}\text { No } \\
\text { Observations }\end{array}$ & 120 & 120 & 120 & 120 & 112 \\
\hline $\begin{array}{l}\mathrm{R}^{2} \\
\text { Individual }\end{array}$ & 0.9751 & 0.9292 & 0.9699 & 0.8516 & 0.8865 \\
\hline Effects & Yes & Yes & Yes & Yes & Yes \\
\hline Time effects & Yes & Yes & Yes & Yes & Yes \\
\hline
\end{tabular}

Note: $* \mathrm{p}<.10, * * \mathrm{p}<.05, * * * \mathrm{p}<.01$

647

648

Table 5: Relationship between FDI and domestic Innovation

\begin{tabular}{|c|c|c|c|c|c|}
\hline & Total & Coal & Electricity & Gas & Oil \\
\hline State & $0.2014 * * *$ & 0.431 & $0.217 * *$ & 0.0088 & 0.184 \\
\hline Collective & $0.5015^{* *}$ & 0.6807 & 0.307 & $0.0538 *$ & -0.297 \\
\hline Cooperative & 0.2181 & $0.4922 * *$ & $0.4990 * * *$ & $-0.282 * *$ & $-0.8968 * *$ \\
\hline Joint & 0.9648 & $0.7643 * *$ & -0.0283 & -0.135 & $-0.1534 * * *$ \\
\hline Limited & $0.1523 * *$ & $0.4878 * * *$ & -0.0272 & 0.0016 & $-0.396 *$ \\
\hline Share-holding & 0.469 & $-0.5352 * *$ & 0.0875 & $0.0802 * * *$ & $0.3355 * * *$ \\
\hline Private & $-0.2052 * * *$ & -0.882 & -0.154 & $-0.0261 * *$ & $-0.698 * *$ \\
\hline Self-Employed & -0.3401 & 0.587 & -0.417 & $-0.0712 *$ & $-0.3576^{* * *}$ \\
\hline Foreign & $-0.5420 * * *$ & -0.3219 & 0.47 & -0.251 & $0.2468 * * *$ \\
\hline Industry & $0.2636 * * *$ & $0.5062 * * *$ & $0.414 * * *$ & -0.0088 & $0.311 *$ \\
\hline Patents & $-0.238 * * *$ & -0.13 & $-0.0203 * * *$ & $-0.0031 * * *$ & 0.0245 \\
\hline Electricity Price & $-0.772 * * *$ & $-0.2552 * * *$ & 0.0447 & -0.0034 & \\
\hline Foreign $x$ Patents & $0.4982 * * *$ & 0.1636 & -0.0401 & 0.0316 & $-0.2276 * * *$ \\
\hline Oil Price & & & & & -0.0884 \\
\hline No Observations & 120 & 120 & 120 & 120 & 112 \\
\hline $\mathrm{R}^{2}$ & 0.9614 & 0.9359 & 0.9698 & 0.8629 & 0.9076 \\
\hline Individual Effects & Yes & Yes & Yes & Yes & Yes \\
\hline Time Effects & Yes & Yes & Yes & Yes & Yes \\
\hline
\end{tabular}


Table 6: Relationship between Imports and Domestic Innovation

\begin{tabular}{lrrrrr}
\hline & \multicolumn{1}{c}{ Total } & \multicolumn{1}{c}{ Coal } & Electricity & \multicolumn{1}{c}{ Gas } & \multicolumn{1}{c}{ Oil } \\
\hline State & $0.1780 * * *$ & 0.355 & $0.219 * *$ & $0.0114^{*}$ & 0.163 \\
Collective & $0.7338 * * *$ & 0.7473 & 0.322 & 0.0309 & -0.999 \\
Cooperative & 0.2378 & 0.3963 & $0.4858 * * *$ & $-0.272 * *$ & $-0.6500 * *$ \\
Joint & 0.1387 & $0.8394 * *$ & 0.132 & -0.127 & $-0.1373 * * *$ \\
Limited & $0.1438 * *$ & $0.5273 * * *$ & -0.0245 & 0.0029 & -0.108 \\
Share-Holding & 0.0873 & $-0.6934 * * *$ & 0.0831 & $0.0910 * * *$ & $0.2911 * * *$ \\
Private & $-0.1530 * *$ & -0.476 & -0.175 & $-0.0249 * *$ & -0.633 \\
Self-Employed & -0.3452 & -0.554 & -0.403 & $-0.0740 *$ & $-0.3059 * * *$ \\
Foreign & -0.3011 & $-0.1418 * *$ & 0.137 & 0.0050 & 0.1023 \\
Imports & $\mathbf{- 0 . 4 9 4 9 * * *}$ & $\mathbf{- 0 . 4 2 7 9 * * *}$ & $\mathbf{- 0 . 1 0 9}$ & $\mathbf{0 . 0 2 4 3}$ & $\mathbf{0 . 1 9 2 2} * *$ \\
Industry & $0.2144 * * *$ & $0.4545 * * *$ & $0.417 * * *$ & -0.0062 & $0.481 * * *$ \\
Patents & $-0.268 * * *$ & $-0.225 * * *$ & $-0.0215 * * *$ & -0.0013 & 0.0079 \\
Electricity Price & $-0.770 * * *$ & $-0.2689 * * *$ & $0.0506 *$ & -0.0045 & \\
Imports $\boldsymbol{x}$ Patents & $\mathbf{0 . 4 6 7 * * *}$ & $\mathbf{0 . 4 0 8 * * *}$ & $\mathbf{0 . 0 0 9 6}$ & $\mathbf{- 0 . 0 0 2 1}$ & $\mathbf{- 0 . 1 8 3 * *}$ \\
Oil Price & & & & & -0.0817 \\
\hline No Observations & 120 & 120 & 120 & 120 & 112 \\
R ${ }^{2}$ & 0.9681 & 0.9346 & 0.9703 & 0.8562 & 0.8987 \\
Time Effects & Yes & Yes & Yes & Yes & Yes \\
Individual Effects & Yes & Yes & Yes & Yes & \multicolumn{1}{c}{ Yes } \\
\hline
\end{tabular}

653 Table 7: Summary of the Results, Investment Ownership and Regional Dimension

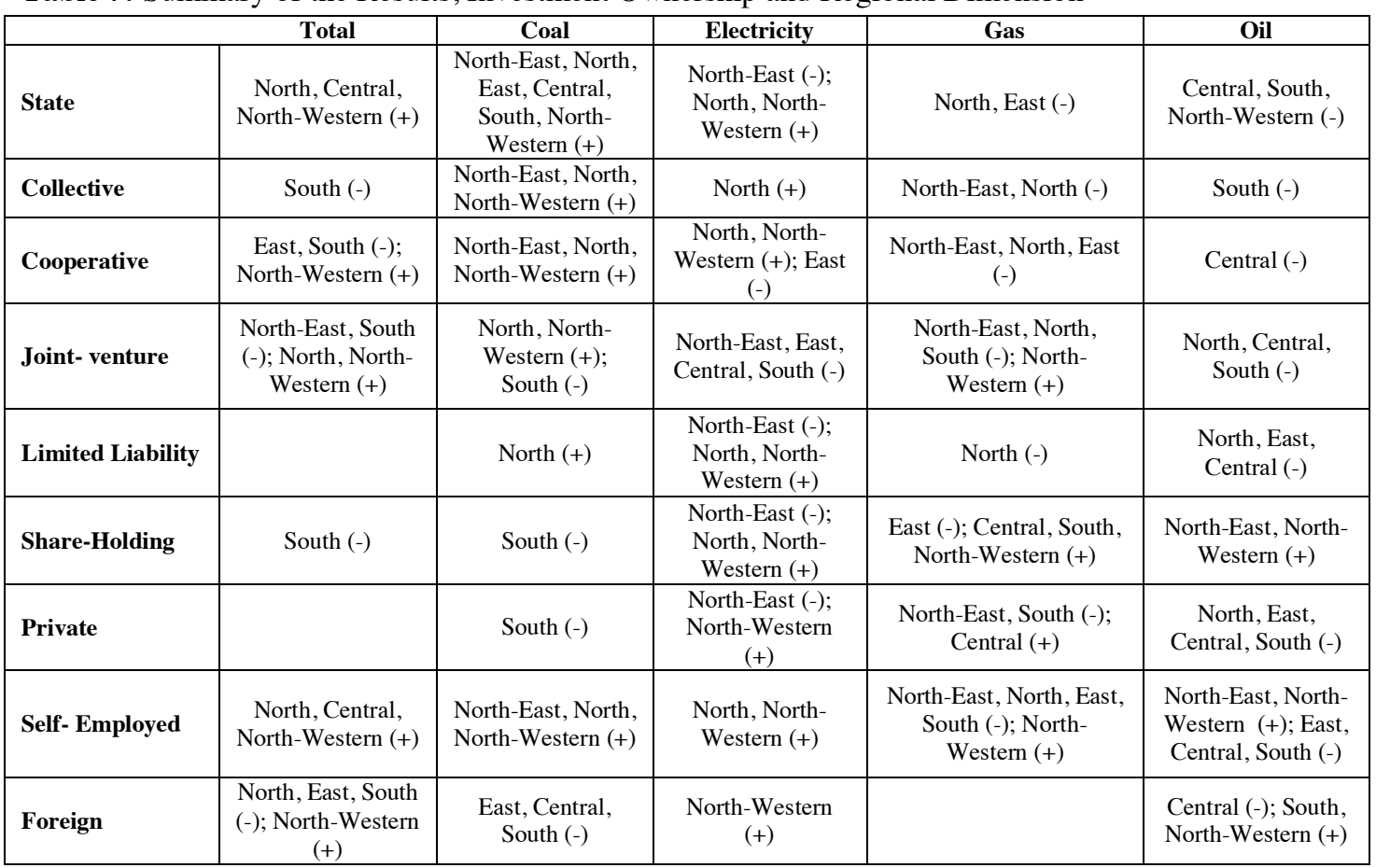

654 Note: We include in the table those results, which are robust to different specifications. A complete statistical analysis

655 is available upon request by the authors. The sign of the effects appears in brackets. 
a) State-Owned Investment

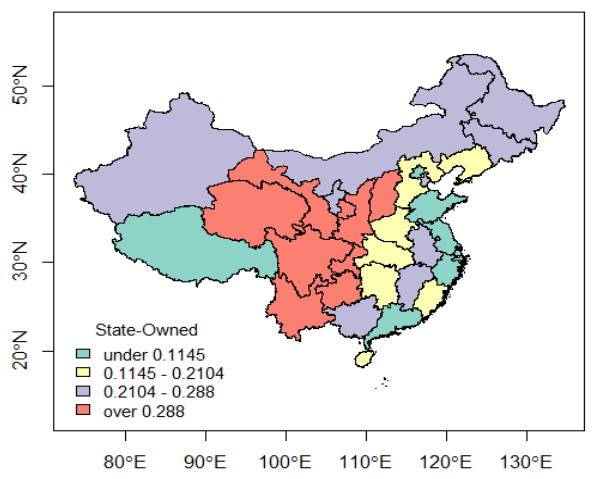

c) Cooperative

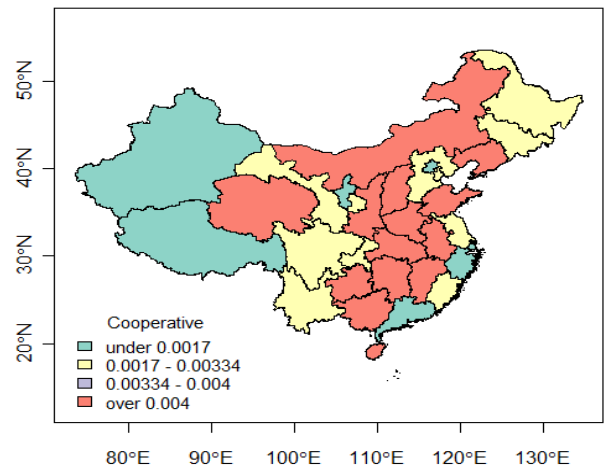

e) Limited

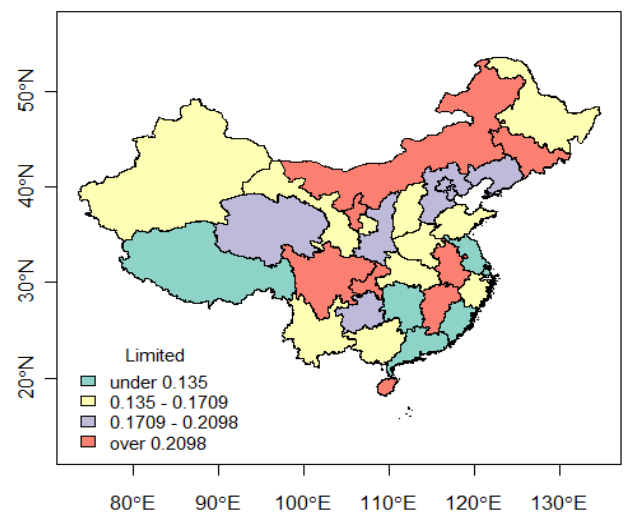

b) Collective

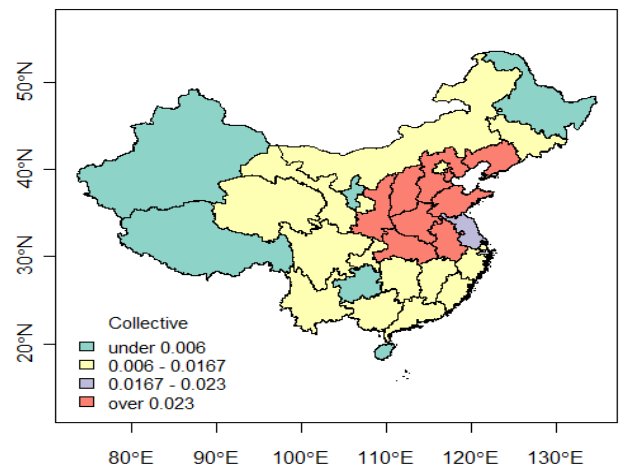

d) Joint-Venture

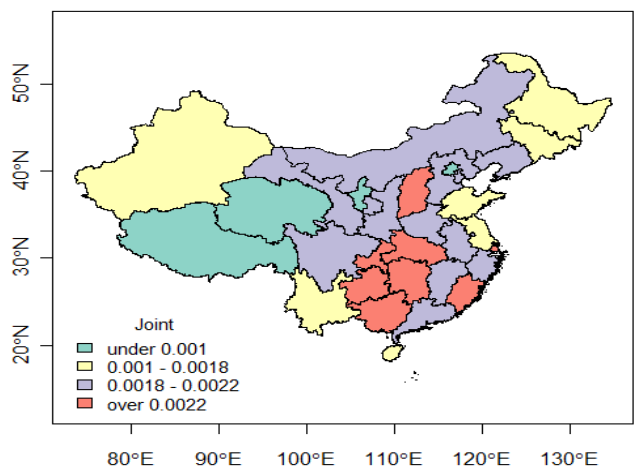

f) Share-Holding

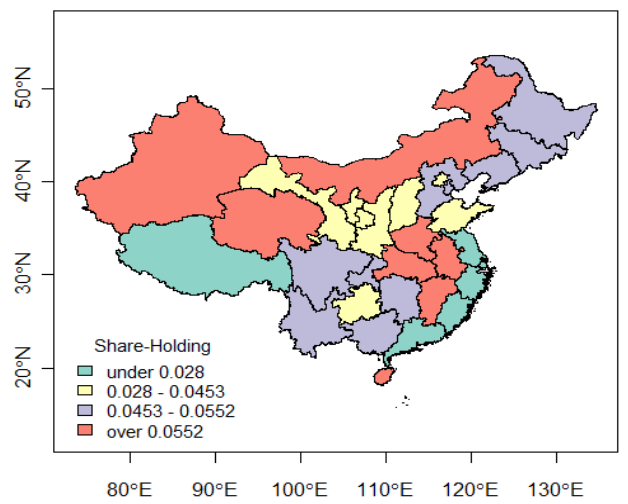


g) Private

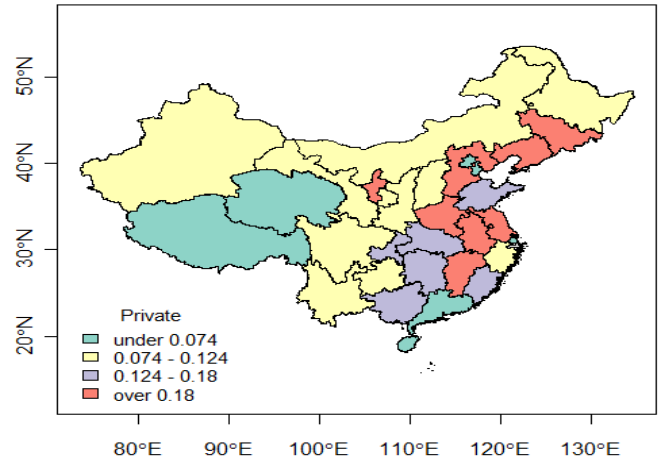

i) Foreign

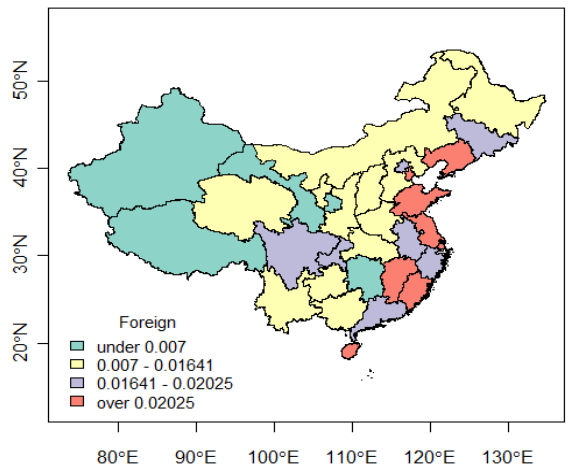

h) Self-employed

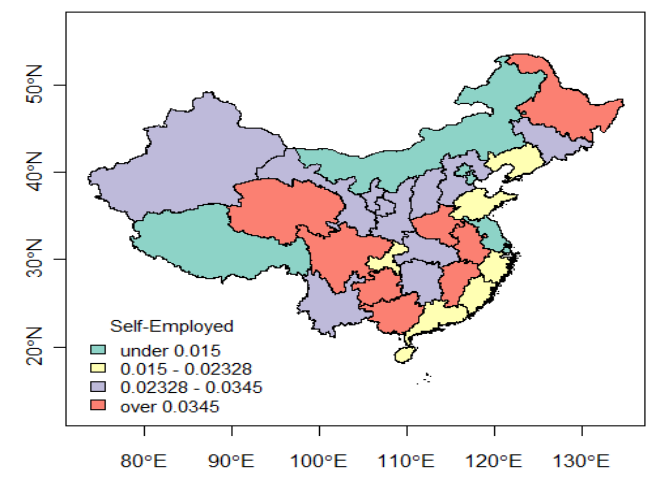


Figure 2: Map of the Transmission Grid

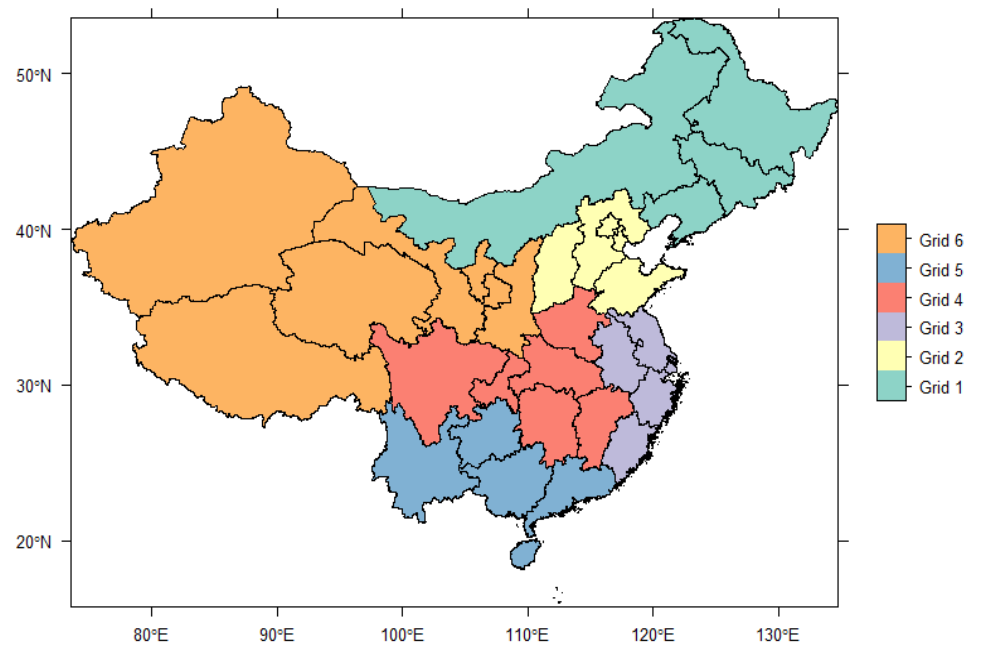

Source: Herrerias et al. (2013a)

Grid 1: North-East $=1$ for Heilongjiang, Jilin, Liaoning and Inner Mongolia; 0 otherwise

Grid 2: North = 1 for Beijing, Tianjin, Hebei, Shanxi and Shandong; 0 otherwise

Grid 3: East = 1 for Shanghai, Zhejiang, Anhui, Jiangsu and Fujian; 0 otherwise

Grid 4: Central = 1 for Jiangxi, Henan, Hubei, Hunan, Chongqing and Sichuan; 0 otherwise

Grid 5: South = 1 for Guangdong, Hainan, Guangxi, Yunnan and Guizhou; 0 otherwise

Grid 6: North-Western = 1 for Shaanxi, Gansu, Qinghai, Ningxia and Xinjiang; 0 otherwise 